\title{
The Indian Women Writers and their Contribution in the World Literature- A Critical Study
}

\author{
Dr. Racheti Anne Margaret \\ M.A, M.Phil, P.G.D.T.E, PhD, Head, Dept. of English \\ SVKP Degree College, Podili, Prakasam D.T. A.P. INDIA
}

\begin{abstract}
The Indian women writers who expressed their views and agony through their writings in the Postcolonial times for two major reasons. First, both patriarchy and imperialism could be seen to exert different forms of domination over those subordinate to them. Because of this, it was important for the experiences of women under the patriarchal influence to come out to the forefront and expose the undue cruelty be held on them by men. It was necessary for the women to oppose this male dominance over them. We observe that women continued to define the borders of the community, class and race. They tried to express their agony and dissatisfaction of male dominated attitude through their works. Though the Indian women writers try to depict the women as strong and focused in their vision to succeed in lives, they were, however, ablest to succeed in their lives only in the space allotted to them by the men.

However, the Indian women writers who tried to stamp their authority in a male dominated environment as best as it is possible to them. They know very well that it is a very difficult path, as the women had to break through years of male dominance, taboos and beliefs that had heavily impregnated the society. In addition, critics argued that colonialism operated very differently for women and for men. It is so because women are subjected to both general discrimination as colonial toys of subjects and specific discrimination as women addressed as 'double colonization.
\end{abstract}

Keywords: Agony, dissatisfaction, toys, Male dominated society, discrimination.

\section{INTRODUCTION}

There are many Indian women writers both novelists and poets, based in the USA and Britain. Some like Jhabvala and Anita Desai are late immigrants while others, like Jhumpa Lahiri belongs to the second generation of Indians abroad. Most expatriate writers have a weak grasp of actual conditions in contemporary India, and tend to recreate it through the lens of nostalgia. Their best works deal with the Indian immigrants, the section of society they know at first hand. Sunithi Nam Joshi, Chitra Benerji, Divakarvas and Bharathi Mukherjee are the oldest, and naturally, the most prolific.

Writers like Jumpha Lahari, Manju Kapoor, Kiran Desai, and Arundhati Roy too have written novels of Magic Realism, Social Realism and Regional fiction, and benefited from the increasing attention that this fiction has received National and International awards. They have probed into human relationships, since the present problem is closely concerned with mind and heart and the crusade is against age-old established systems. In order to make the process of changes smooth and really meaningful, women writers have taken upon themselves this great task.

Away from this line of writing the lives of women, the most successful of the Indian women writers is Jhumpa Lahiri who created the difference among all the Indian women writers. She is a dazzling storyteller with a distinctive voice. She is different from other Indian writers writing in English. Most of the first generation writers of Indian fiction are born and brought up in India. But Jhumpa Lahiri's connection with India is through her parents and grandparents. India would appear to her sometimes full of wonders, sometimes full of beggars. Moreover, the writers who live outside comment confidently on economic social and political scenario may appear very often exaggerating or understanding. However, Lahari is honest and authentic to her experiences.

For Lahiri "Every visit was an emotional see-saw across continents and cultures" (204). Lahiri is an Indian by ancestry, British by birth, American by immigration. She targets the Western audience by deliberately portraying the Indian American life. She also admits, "I learnt to observe things as an 
outsider and yet I knew that as different Calcutta is from Rhode Island, I belonged there in some fundamental way, in the way, I didn't seem to belong in the U.S." (The Times of India, 13 April 2000). This sense of freedom is one of the greatest thrills of writing fiction for her and she discovered her authorial freedom by publishing her debut book i.e. Interpreter of Maladies (1999) her debut anthology is collected stories that deal with the question of identity. Her another famouse novel The Namesake (2003) which is essentially a story about life in the United States. But Lahiri says that Namesake deals with Indian immigrants in the United States as well as their children. For instance, though she is much more American than her parents she inherited a sense of exile from her parents. After her Ph.D. in Renaissance studies from BostonUniversity, she had planned to write about her roots and origin. It appears "She is more American than her parents ....her characters move constantly between two worlds grappling bravely with this cultural displacement" (The Times of India, April 7, 2000).

Anitha Desai is the best known of the contemporary women writers. Of all the contemporary novelists, she is indisputably the most popular and powerful novelist. She has made commendable contribution to the Indian English fiction. She is a novelist of urban milieu and is a fine mixture of Indian European and American sensibilities. She is essentially a psychological novelist. She claims that her novels are not reflection of Indian society or character. She does not reflect on social issues in her works like Mulk Raj Anand. She sees social realities from a psychological point of view and does not look at them as a social intimate expression of the inner world of her characters. She makes each of her work a haunting exploration of the psychic self. Her last novel Baumgartner's Bombay, written at Griton College, Cambridge, was published in 1988. In the nineties, she has not published any novel as yet. Thus, she has double sensibility, which gives her novels an objective effect. She however travelled widely in almost all the parts of India and her experiences of different sort of people and places have enriched her writing. Moreover, the same is true of Nayantara Sahgal, whose last novel Plans for Departure, published at the turn of the decade got her the Sahitya Academy Award.

The novelist with the most sustained achievement is Shashi Desh Pande who is labeled as feminist novelist succeeded in depicting the plight of a successful educated woman and problems of being a woman. She has written eight novels, six collections of short stories, and four children's books. Her popular novel The Dark Holds No Terror (1980) portrayed the life of a woman who marries a doctor and becomes the victim of brutalization. It is a story of courage and perseverance that she developed from within herself to break loose of society's traditional norms to gain her individuality and freedom. She has achieved tremendous amount of popularity through her writings. She depicts the Indian middle class mentality in all her novels. Her protagonist emerges from cultural rootedness in middle class Indian Society. Desh Pande generally has the heroine as the narrator and employs a kind of stream - of - consciousness technique. In another novel Roots \& Shadows (1983), we are introduced to another rebellious woman who refuses to accept traditional family life and escapes to the city to work. She later marries a man of her own choice. As time goes by, she realizes that life in the city is no different from the village. Almost all her novels deal with a crisis in the heroines' life. Her work is women-oriented, but it would not be correct to term her a feminist, as she consistently rebates with the feminist identity. She simply portrays, in depth the meaning of being women in modern India.

Shashi Desh Pande's novel That Long Silence (1988) is viewed as her emergence as a major novelist. This novel won her the Sahitya Academy award for 1990, tells the story of an Indian housewife Jaya, an upper-middle class house wife who maintained her silence in Bombay throughout her life in the face of hardships that threaten to break it. The lack of depth in a woman's life is clearly depicted in this novel. She however, shows us that most of the family rules like the idea of trying to secure one's life by marrying a wealthy man and establishing a name in society by sending children to good schools, is shown how mundane, meaningless and mechanical a woman's life really is partly selfimposed by women themselves. In another novel A Matter of Time (1996), attempts to depict three generations of female human relationships. In her latest novel Small Remedies (2000), as we read this novel, we realize her over possessive attitude. This is a novel that dwells into the various aspects of motherhood. At last, Her, The Binding Vine, compels one to discover how the 'binding vine' of human emotions links and sustains diverse human beings as they go through life.

Manju Kapoor is also one of the significant writers whose work establishes the nexus between the tradition and modernity. The dominating works of Kapoor can be critically seen in her significant novel Difficult Daughters (1998), which is her first novel. It was awarded Commonwealth Writers 
Prize for best first book, which has earned her very substantial success both commercially and critically. The novel Difficult Daughters which has been well received by one and all. The story of this novel is set around the time of partition, which is the story of a woman whose battle for Independence engulfs. Her second novel, A Married Woman (2003) which is a quite powerful as its predecessor and thematically even more controversial. But the novel proving Indian and universal achievement.

In the similar fashion, Bharati Mukherjee's fame has shot up in the recent years as an Indian American writer. Her novels Wife, Jasmine, The Holder of the World, Leave It to Me and DesirableDaughters make a bold attempt to rewrite the origins of America's history in the light of wider American experience. For instance her second novel Wife (1975), she writes about a woman named Dimple, who suppressed by men attempts to be the ideal Bengali wife, but out of fear and personal instability murders her husband. Her best fiction Jasmine (1989) develops the idea of the synthesis of the East and West with a story telling of young Hindu women, who leaves India for U.S. after her husband's murder as an illegal immigrant. Her fourth novel, The Holder of the World (1993), attempts to integrate contemporary travelogue and ancient history. This novel too has the theme of transformation and migration, but with a difference. Her fifth novel Leave It To Me (1997) is completely American. The only Indian touch is the prologue, which retells the mythological story of is the goddess, who killed the Buffalo Demon. This book is soaked in blood and reeks in violence. Her last and sixth novel is Desirable Daughters (2002) which acts as a bridge between transformation and migration and piles up meticulous details in the information. However, Bharati Mukherjee recaptures history in the most aesthetic sense. She continues writing about the immigrant experience in the most of her stories like in The Middle Man and Other Stories, a collection of short stories, which won her the National Book Critics Circle Award.

Gita Mehta is also another woman writer who proclaimed about the problems of the contemporary immigrant women with sublime standards. She wrote Snakes and Ladders andGlimpses of Modern India in 1997. It has become most widely read book particularly by those unfamiliar with India. In an interview, she said that her intention was "to make modern India accessible to westerns and to a whole generation who have no idea what happened before they were born" (24) (An Interview with C.J.S.Wallia). Gita Mehta's first novel is Raj (1989) which is a very powerful and enlighting readable novel. It is considered to be one of the great historical novels of our time. Raj is the story of the Maharani Jaya Singh, as well as the drama of India's struggle for Independence. However, Mehta's unique nature is to collect the richness of living is this rarity of perspective that gives her a witty ability to define her vision for India by her novels.

Arundhati Roy is the luminary among the contemporary women writers. She is one of the women writers who wrote about the plights of the downtrodden and the suppression of women in a male dominated world and the influence of Marxism on the lives of the downtrodden. When women writers maintained their reservations in offering a critical evaluation of Indian politics, Arundhati Roy emerged as a beacon of light to guide the Indian women writers. She has got overwhelming reception with The God ofsmall things (1997), which has put her in the forefront of all the other writers. Her success with just the publication of her single book has already placed her on equal terms with Salman Rushdie and others. Moreover, She has surpassed even Vikram Seth's A Suitable Boy. The characters are entirely imaginary, with no factual correspondence to real life characters. Arundhati Roy mentions the Veteran Marxist E.M.S Namboodaripad by name, but proceeds to invent fictions about him, which led to widespread protests in Kerala, the state where he headed the first elected communist Government in world history. It is also a comprehensive protest novel, which describes atrocities against the powerless, children, women and untouchables.

Arundhati Roy is the only novelist, who being an activist, is constantly writing about social problems. Her monograph, The Greater Common Good (1999) which reveals the truth about the Narmada Project. The book also shows her talent as an essayist and social reformer. Her earlier essay The End of Imagination (1998) which urged nuclear disarmament. She is the winner of Booker Prize as well as the Sidney Peace Prize. 


\section{Conclusion}

In the contemporary Indian Literary scenario, Indian women writers in English who reflect the truth of Indian reality. They bear numerous responsibilities in the world of literature. They execute with admirable aplomb as the anthropologists, sociologists, novelists, essayists, travel writers, teachers and slip into global responsibility for establishing peace as the ambassadors. They have excelled the global literary standards set by the post-colonial and postmodern writers men and women like Salman Rushdie, Vikram Seth, Vikram Chandra, Sashi Tharoor and Arundhati Roy etc. These have become the colossal central socio literary figures with the substantial bodies of work drawing the global attention. They also have become the only negotiators to mediate the core social and cultural problems of India and other colonized nations. All their major works have enjoyed immense academic attention across the globe and which have invited and produced a great amount of literary criticism especially on feminism. They have created a wide readership and a strong critical endorsement that reflect the attention of serious academicians and scholars. All the post-colonial and postmodern predicaments are wrestled to demonstrate a high level of self-consciousness, which continue, interrogate the social, philosophical, cultural issues of rape and sexual harassment of innocent women in the contemporary Indian society. Their works have initiated the emergence of critique of feminism with nationalism. Their intellectual insights, conceptual, theoretical and textual experiments have engaged and interpreted the complex colonial and postcolonial situations. They have also established a peculiar paradox of reading and appreciation eloquently responding to the issues of sexually harassed women both in post-colonial and postmodern issues of rape and exploitation on the Indian women in the contemporary society.

\section{REFERENCES}

Asnani, Shyam. New Dimensions of Indian English Novel. Delhi: Doaba House, 1987. Print.

Barry, Peter. Biginning Theory: An introduction to literatary and Cultural theory. Manchester and New York: ManchesterUniversityPress. 1995. Print.

Betty, Frieday. The Feminine Mystique. New York. Dell, 1963. Print.

Bhabha, Homi. K.Nation and Narration and The location of culture. New York: Routledge. 1990, 1994. 5 March 2010. Print.

Bhargava, Rajul. 9ed.) Indian Writing in English: The Last Decade. New Delhi; Rawat, 2002. Print.

Desai, Anita. Baumgartner's Bombay,London: Penguin, 1989. Print.

Deshpande, Shashi. That Long Silence, New Delhi: Penguin India, 1989. Print.

Mukherjee, Bharathi. Wife. New York: Houghton, 1975. Print.

Jasmine.New Delhi: Penguin, 1990. Print.

Mukherjee, Meenakshi. 'ThePerishable Empire: Essays on IndianWritingin EnglishNew Delhi: OxfordUniversityPress.2000. Print.

Naik, M.K. A History of Indian English Literature. New Delhi: Sahitya Akademi. 1982. Print.

Indian English Literature 1980-2000: A Critical Survey.Delhi: Pencraft International.2001. Print.

Ravi, P.S. Modern Indian Fiction: History, Politics and Individual in the Novels of salman Rushdie, Amitav Ghosh and Upamanyu Chatterjee New Delhi: Prestige Books, 2003. Print.

Recent Indian Fiction edited by R.S.Pathak, Prestige books: New Delhi. 1994. Print.

Roy, Arundhati..The God of Small Things. New Delhi: IndiaInk. 1997. Print.

Robison, Lillian. In her work Sex, Class and Culture. 1978. Print.

Sahgal, Nayantara. Plans for Departure 1989. Print.

Sealy, Allan. Trotter-Nama 1988 and Hero 1990 through the LiteratureAlive, 1990: 25. Prints

Sen, Asha. 'Towards a National Culture? India and its Diasporas'Diss, Purdue University, 1996. Print.

"The Novels of Our Times," The Hindustan Times, 27 February 1993: 4. Print.

Warner, Michael. "Literary studies and the History of the book": Book 12, 1987. Print. 


\section{AUTHOR's BIOGRAPHY}

Dr. Racheti Anne Margaret, awarded her $\mathrm{PhD}$ degree in the Acharya Nagarjuna University, GUNTUR, Andhra Pradesh, India (2009), her M.A., M.Phil, from Sri Venkateswara University Tirupati and P.G.D.T.E. also happened in CIEFL, Hyderabad. She is now teaching English Literature and Phonetics in SVKP Degree College, Podili and published several other articles in reputed international journals. She has participated National and International seminars/conferences. 